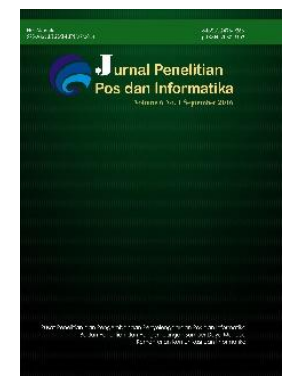

JPPI Vol 9 No 2 (2019) 85 - 96
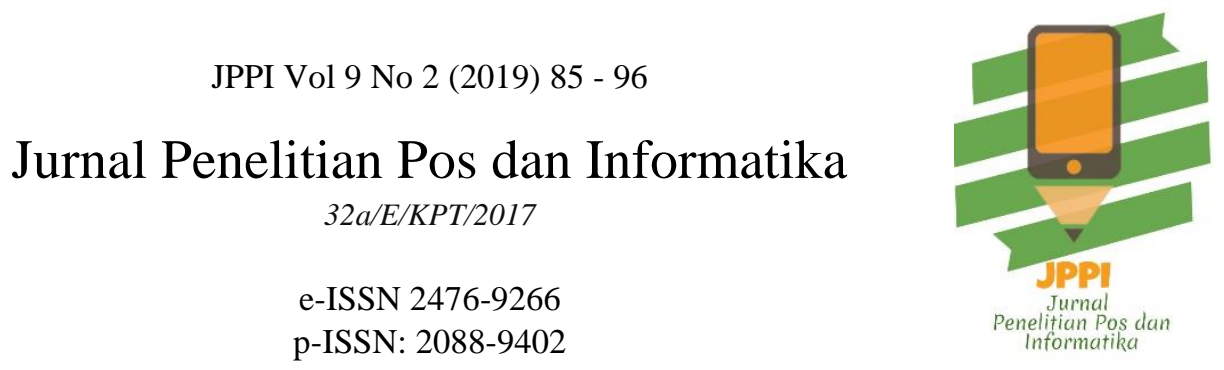

Doi:10.17933/jppi.2019.090201

\title{
INDONESIA'S PUBLIC APPLICATION PROGRAMMING INTERFACE (API)
}

\section{APPLICATION PROGRAMMING INTERFACE (API) PUBLIK INDONESIA}

\author{
Nur Aini Rakhmawati ${ }^{1}$, Sayekti Harits Suryawan², Muhammad Ariful Furqon ${ }^{3}$, Deny \\ Hermansyah $^{4}$ \\ ${ }^{1234}$ Information Systems Department, Institut Teknologi Sepuluh Nopember Surabaya, Indonesia \\ Inur.aini@is.its.ac.id \\ Naskah Diterima: 16 January 2018; Direvisi : 21 May 2019 ; Disetujui : 18 September 2019
}

\begin{abstract}
Indonesia places the fifth position of the most internet users in the world. Consequently, data transaction through HTTP protocol saw an increase. An open API can facilitate Indonesia's users to access data and build application through HTTP protocol. In this paper, 38 open APIs were investigated and classified by using five criteria, namely technology, authentication, scope, source, and approval request. In general, the open APIs in Indonesia employ RESTful as a web service and JSON format as data format. In term of authentication, API key is a common method in most of open APIs.
\end{abstract}

Keywords: Indonesia application programming interface, open API, web services, 


\section{INTRODUCTION}

An open API, also known as a public API, is an application programming interface which is publicly available for everyone such as developers with programmatic access to the interface. API allows software development without having to develop software from scratch. In addition, API owners can retain their code while gaining more publicity for their products.

Recently, Indonesia places the fifth position of the most internet users in the world[1]. Thus, open API is considered as one of the enablers of technology and data growth in Indonesia. For instance, the Indonesian Government introduced an initiative for open government to drive its citizens' involvement in development. Moreover, the open government can enforce all administrative units to involve the citizen in the development planning process through "Perencanaan Pembangunan (development planning)" forum [21]. Meanwhile, on an economic viewpoint, based on Global B2C E-Commerce Report 2016, Indonesia experienced approximately $60 \%$ E-commerce sales growth in 2015[3]. Piao concluded that an open API platform could facilitate the development of the innovative application for third-party developers namely 1) establishing a business without significant investment both in software and hardware; 2) contributing to driving traffic to the platform[4]. As a result, the open API technologies potentially broaden the E-commerce business model and boost the sales growth of the ecommerce business.

However, to date, Indonesia is lacking open API. In

\footnotetext{
${ }^{1}$ https://www.bukalapak.com/
}

the case of open government, Indonesia is at an early stage and needs to develop awareness on the matter of open data and policy to support the initiatives [5]. By showing its commitment to open government by participating in Open Government Partnership [2] as a result, currently, government's open data initiatives begin to emerge as open API. For instance, "Jakarta API" which is developed by Jakarta Smart City. Hence, to start an initiative of open data with open API technology, we need to review the current condition of the open API availability in Indonesia..

\section{METHODOLOGY}

\section{Indonesia's Public Api}

This section describes a list of public APIs that are used in Indonesia.

\section{A. BukaLapak}

Bukalapak API is an e-commerce API which is officially developed by Bukalapak ${ }^{1}$ Development team. The API provides open API to develop innovative third-party software Development Competition. Bukalapak API provides products, transactions, and users. Bukalapak API uses REST technology to communicate between Bukalapak server and clients and uses JSON format for communication.

\section{B. MatahariMall API for Seller}

Similar to Bukalapak, MatahariMall API is also an e-commerce API which is officially developed by the MatahariMall ${ }^{2}$ Develompment team. The API documentation provides various resources reference for product management modules and order management modules from a Seller Center API. Both modules are at a high level and intended for

\footnotetext{
${ }^{2}$ https://www.mataharimall.com/
} 
those who want to develop using this API. Moreover, the documentation contains public and private actions that will be used for a specific merchant or seller by implementing a token. MatahariMall API uses the REST technology while using the JSON format for communication.

\section{Tiket.com API}

This API is developed by ticket.com, it enables a user to create its website or mobile application for ticket sales. Tiket.com provides all data. The API exploits REST, which supports JSON, XML, and PHP serialized format. Users are required to register as affiliates of ticket.com ${ }^{3}$. There are two flows of payments that can be considered in using the API:

1. Deposit: by putting money on deposit at Tiket.com, a user can manage his transaction and payment. API will return insufficient funds when deposits are low. Thus the transaction will be failed.

2. Regular: Tiket.com offers another payment channel where users can charge their customer for a transaction. The transaction can be paid by using bank transfer and payment gateway (credit card and BCA KlikPay).

\section{Bisatopup}

Bisatopup API enables a user to create apps for purchasing mobile phone prepaid credits, Internet Packages, electricity tokens, Game Vouchers and bills payment through bisatopup.com. The API consists of Product List, Product Price, Check Bills. Bisatopup officially develops the API by using the REST technology and JSON format for communication.

\footnotetext{
${ }^{3}$ https://www.tiket.com/affiliate

${ }^{4}$ https://midtrans.com

${ }^{5}$ https://ipaymu.com/
}

\section{E. Jurnal API}

Jurnal API enables developers to integrate between their system and online accounting software platforms developed by Jurnal.id. The API is built based on REST technology and will return JSON formatted data upon the requests. To use the API, users are required to have an existing active company in their application. The API is only for the user of Jurnal.id.

\section{F. Midtrans - Payment Gateway}

Midtrans API is an online payment gateway service API which is officially developed by PT Midtrans ${ }^{4}$. Midtrans API uses RESTful technology and JSON format to serve a communication bridge between merchants as users and Midtrans's payment channels.

\section{G. iPaymu}

iPaymu API is an online payment gateway service API which is officially developed by PT. INTI PRIMA MANDIRI UTAMA ${ }^{5}$. iPaymu API uses REST technology and supports both XML and JSON format to support communication between merchants as users and Midtrans' payment channels.

\section{H. Hot Thread Kaskus (Un-official)}

Hot Thread Kaskus API is an unofficial Kaskus ${ }^{6}$ forum API Developed by Bayyu ${ }^{7}$ using a web scraping technique. The API was developed using REST technology and using the JSON format for communication between clients and server.

\section{Data Jakarta}

Jakarta smart city ${ }^{8}$ Is one of the initiatives for

\footnotetext{
${ }^{6}$ https://www.kaskus.co.id/

${ }^{7}$ Bayyu.net

${ }^{8}$ http://api.jakarta.go.id/
} 
Indonesia open government. Jakarta API that is developed by Jakarta Smart City. It provides a public data service in Jakarta as such as data on the region, hospitals, CCTVs, busway routes, etc. The API uses REST technology and JSON format for communication between client and server.

\section{J. Kaskus API}

Kaskus API is an API for accessing the most popular forum in Indonesia. Kaskus API base URI is located at https://www.kaskus.co.id/api/oauth (without trailing slash) and will be referred to BASE_URI. The API is RESTful. Data is exposed in the form of URIs that represent resources and can be fetched with HTTP clients (like web browsers). This API is developed by Kaskus Development team.

\section{K. Tanggal Lahiran Pasaran Zodiak}

This API developed by iBachor is used to learn the signs of zodiacs based on date of birth. It also shows details on date of birth, age, and birthday.

\section{Cek Resi}

This API is used for tracking receipt of the popular expeditions companies in Indonesia such as JNE, SiCepat, and Wahana. Cek resi API is located on https://www.wahidganteng.ga/api/cek-resi.

\section{M.Paket ID}

Similar to CekResi, Paket ID API is also used for tracking shipment. The API version 2 uses universal authorization (auth-user-email and auth-API-key) The API is developed by Paket.id.

\section{N. Raja Ongkir}

Two previous APIs are used for tracking shipment. Rajaongkir is used for obtaining information about shipping cost such as JNE, POS,
TIKI, etc. RajaOngkir API employs RESTful where the data are taken from each of the expedition websites to maintain data accuracy.

\section{O. Jadwal Shalat}

This API presents prayer time schedule by city or date. The API is located on https://www.wahidganteng.ga/api/jadwal-sholat.

This API developed by Wahid.

\section{P. Ayo Donor PMI}

Ayo Donor PMI API can capture Indonesian Red Cross' activities, particularly in terms of bloodstock. This API consists of Blood Stock, and Blood Transfusion schedule. This API is developed by iBachor.

\section{Q. Halal Product MUI}

Halal Product MUI is an API for searching halal products registered by the Indonesia Ulema Council (MUI). The API provides information including product names, certificate number, manufacturers, and validity period of the halal certificate. This API is developed by iBachor ${ }^{9}$. The Halal data are obtained from the MUI halal product website. The API uses RESTful, which provides access to halal information.

\section{R. The departure of Hajj Eestimation}

The departure of Hajj estimation is an API for predicting the estimated departure of Hajj. This API is developed by iBachor $^{1}$ by exploring the Indonesian Ministry of Religious Affairs' website. It also uses RESTful web services and JSON. The input of the API is the unique number given by the Indonesia's Ministry of Religious affairs.

\footnotetext{
${ }^{9}$ https://bachors.github.io/
} 
S. Emergency Contact (Police, Firefighter, Hospital)

Emergency Contacts is an API that provides police, firefighter and hospital contact numbers and address. This API is developed by Farizdotid ${ }^{10}$ and can be accessed by using RESTful architecture and presented the data in JSON.

\section{T. Kemendag}

Kemendag API provides information about the price of stapple commodities in Indonesia that are provided by the Ministry of Trade of Indonesia . The information includes the commodity name, unit, and the price. This API was developed by iBachor ${ }^{1}$ by scrapping the table of stapple commodities price on Indonesia's Ministry of Trade's website. It also uses RESTful web service and JSON to provide access to users.

\section{U. Song Lyrics}

iBachor also developed an API for searching song lyrics by using RESTful as a web service and JSON format.

\section{Area Name in Indonesia}

This API provides a list of areas in Indonesia, including provinces, regencies, cities, sub-districts, and villages. RESTful and JSON are web service technology used by Farizdotid ${ }^{2}$ for developing the API.

\section{W.Lapor!}

Lapor! is an API which is officially developed by State Ministry of the Empowerment of State Apparaturs and Bureaucratic Reform of Indonesia. The API is part of a citizen reporting management system. Lapor! uses RESTful API to integrate the

\footnotetext{
${ }^{10}$ https://farizdotid.com/
}

services of data access and report of Lapor! API. Lapor! Data Access is in JSON format for communication, meanwhile Lapor! Report integration uses XML format for communication. The Lapor! Mobile app is one example application used the API.

\section{Postal Code}

Postal code is an API that provides the list of postcodes in Indonesia. This API was developed by iBachor $^{1}$ and Widnyana Putra ${ }^{11}$. RESTful web services and JSON format are the Technologies for developing the API.

\section{Y. API Pemilu}

In 2014, Indonesian Association for General Elections and Democracy (Perludem), is one of civil society organizations that utilizes and optimizes general election data and information [20]. In collaboration with the Asia Foundation, Perludem implements the API for collecting the general election data. The collected data is converted to machine-readable format and stored in online storage that can be accessed freely by anyone. The storage supports RESTful web service and supported by XML and JSON technology. The API Pemilu has been implemented for some applications such as 1) Pemiluman App; 2) Pemimpin Kita; 3) Pemilu Kita; 4) One Vote; 5) Caleg store, etc.

\section{Z. Mandiri e-cash}

Mandiri e-cash API provides solutions for companies/organizations to perform operational, financial management from/to employees/members. The transaction receipt of payments is made by a host-to-host method through open-API. There are two principal transactions which are handled by API:

\footnotetext{
${ }^{11}$ http://widnyana.web.id/
} 
1. Operational Fund Management. eCash is used by employee/member account of the organization for debiting contributions, claims and deposits from employees/members to a company.

2. Receipt of Payment eCash can be used to make payments to the Company's Partner (Merchant) by the eCash holders. It is intended for people who do not have a debit or credit card.

Bank Mandiri Developer officially develops Mandiri e-cash based on RESTful web service technology and supported by JSON format as response protocol.

\section{AA. API BPJS Kesehatan}

API BPJS Kesehatan is an official API which is developed by Social Security Administrative Body (BPJS) based on RESTful and JSON technology. To access the API, a user is required to have a Consumer ID and Consumer Confidential data. The service consumer only stores consumer-confidential information to maintain security. The Consumer confidential information generates a Signature (Xsignature). A list of services provided by this API are: 1) Finding participants based on the BPJS card; 2) Finding participants by identity card number or NIK; 3) Searching referral data by reference number;

4) Searching referral data based on BPJS card; 5) Searching list of referenced patients based on the referral date; 6) Making SEP, etc.

\section{BB. API BCA}

Bank BCA develops a list of open APIs which can be used by third-party developers such as business banking API, Sakuku API, and General Information. BCA developers officially developed those APIs by implementing RESTful web services and JSON. BCA APIs are using OAuth 2.0 as the authorization framework. To obtain an access token, a user has to be authorized by a client_id and client_secret. A signature is used by BCA to verify that attackers do not alter the request. This api provides the following services: 1) balance information; 2) account statement; 3) fund transfer; 4) create payment; 5) payment status; and 6) general information (foreign exchange rate, deposit rate, and nearest ATM locator).

\section{Open Data Kota Bandung}

Open Data Kota Bandung developers developed an API based on CKAN API ${ }^{12}$. CKAN Action API is a powerful, RPC-style API that exposes all of CKAN core features to API clients. CKAN API also uses RESTful web service. The parameters for the API functions are given in the JSON dictionary. CKAN will also return its response in a JSON dictionary.

\section{DD. API Data KPU}

The open data KPU provides web service and JSON. The data provided includes general election, constituency, candidacy, candidate, general election results, etc.

\section{EE. Online Pajak}

As an extension of Online Pajak, its developer developed several open APIs that can be used by third-party client integrator. To access online tax services through the API, Online Pajak provides an additional authentication layer. The setup process consists of two steps: 1) create an API key to authenticate the market and 2) create a User ID for new user to this market's users list. Online Pajak is

\footnotetext{
${ }^{12}$ https://ckan.org/
} 
used for the preparation, payment and reporting of types of tax returns: VAT, Income 21 and Income Tax 23.

\section{FF. Open Data Kota Banda Aceh}

Developer of Open Data Kota Banda Aceh developed API based on the CKAN API. The CKAN API also uses a web service and parameters in the JSON dictionary, and CKAN will also return the response in the JSON dictionary. The services provided are 1) checking a site, 2) displaying metadata from a dataset along with data source, 3) displaying a list of UUIDs from a dataset, displaying a list of all group names, category list, license list, revision list, displaying datasets based on latest updates, etc.

\section{GG. BRI API}

BRI develops several open APIs that can be used by third-party developers such as business banking API, Sakuku API, and General Information. The APIs are based on REST and JSON. The BRI's APIs use OAuth 2.0 as the authorization frame. To obtain an access token, users must be authorized by client_id and client_secret. A signature is used by BRI to verify the request not modified by the attacker. Some services provided by BRI API are 1) balance information; 2) mutation info; 3 ) forex info; 4) make payments; 5) payment status; and 6) general information (foreign exchange rates, and deposit rates).

\section{HH. ATM Bersama API}

This API also implements REST and JSON. There are several services provided by this API, such as bank code in Indonesia, shared ATM

\footnotetext{
${ }^{13}$ https://www.odeo.co.id/

${ }^{14}$ https://kb.klikindonesia.or.id
}

location, cash withdrawal, balance information, third party transfers, payment transfers.

\section{API-H2H Bisnis}

This API is used for ODEO ${ }^{13}$ Affiliation to join their business. API authentication employs tokens. For the JSON format, each request must also include an authorization header in the format of token = base64 (MID + ':' + SECRET_KEY) Authorization: The carrier responds 401 for an invalid request. It is unnecessary for appending an Authorization header in XML format because only MID and SECRET_KEY are required when XML body is sent.

\section{JJ. Klik Indonesia API}

Klik Indonesia API is a single sign-on and app monetizing services developed by Solusi Dua Satu ${ }^{14}$. The API uses a REST technology and is available in JSON format.

\section{KK. Panel-Pedia API}

Panel-Pedia API is an API for selling a bogus endorsement in social media post as such as Facebook's likes, Twitter follows, Instagram likes, etc. Panel-Pedia API is developed by Panel-Pedia15 using the REST technology and available in JSON format.

\section{LL. Satu Data Indonesia API}

Satu Data Indonesia API is an open data API initiated by Unit Kerja Presiden Bidang Pengawasan Pengendalian Pembangunan (UKPPPP) or President Staff for monitoring and assessing development as a commitment for open government partnership ${ }^{16}$. The API provides data from the

\footnotetext{
15 https://panel-pedia.com

${ }^{16} \mathrm{http}: / /$ data.go.id/tentang/
} 
ministries of Indonesia, government institutions, local government and developed based on CKAN API and available in JSON format.

\section{OPEN API CRITERIA}

In this section, we describe a list of criteria used for the classification of the mentioned open APIs. There are five criteria, namely technology, authentication, scope, source and approval request. These criteria were selected for their obvious appearance on API retrieval.

MM. Technology

Technology is a criterion concerning the kind of technology supporting the open APIs.

\section{XML}

XML (Extensible Markup Language) is a commonly used markup language for generating markup documents with the need for data exchange between multiple systems. [6] XML is an extension of HTML (HyperText Markup Language) which is the standard language for the Internet. [7]. XML design can store data with simple and easy management. The XML keyword is the data (plural of datum) that can provide information by processing it. [8] XML provides standardization to describe the contents of the document but can be modified. [9] XML can describe any database view but in a standard way. [9]

\section{JSON}

JSON (JavaScript Object Notation) is a computer data exchange format. The format is text-based and

17 https://data.kpu.go.id/open/v1/doc.php

$18 \mathrm{http}: / /$ apidoc.achilles.systems/

19 http://data.bandaacehkota.go.id

20 http://docs.briapi.apiary.io easy to understand and is used to represent simple data structures and associative arrays (called objects). Transmission of structured data through a network connection to a process called serialization, often uses JSON. Its main application is on AJAX web application programming by acting as an alternative to the traditional use of XML format.

JSON is based on a set of JavaScript programming languages (specifically, the third edition of standard ECMA-262, December 1999 [10]). JSON is a data format independent of a language. Code for creating and managing JSON data has been provided for many types of programming languages. The json.org website provides a comprehensive list of JSON bundles available, organized by language.

The JSON format is specified in RFC 4627 by Douglas Crockford. The official JSON Internet media type is application/JSON while the file extension is .json.

\section{REST}

REST (Representational State Transfer), is a software architecture for distributed hypermedia systems such as WWW. Roy Fielding first introduced this term in 2000 on his doctoral dissertation. REST specifically refers to a network architecture that defines and addresses resources. This term is often used to describe all simple interfaces that pass data in specific domains over HTTP without additional message layers such as SOAP or session tracking using HTTP cookies. It is possible to design an extensive software system by using the REST Fielding architecture style without

21 http://docs.ppob.apiary.io 
using HTTP and interacting with the WWW. The REST allows designing simple XML + HTTP interfaces that do not follow REST principles but instead follow the model of RPC (Remote Procedure Call)[11].

NN. Authentication

There two authentication methods that are widely used in the open APIs are Oauth and Apikey.

Further explanation on both methods are as follows:

\section{OAuth}

OAuth is an open protocol for sharing personal resources (e.g. photos, videos, address lists) stored on a website with other sites without the need to provide a username and password. This process uses a token, not a username and password, for their data is hosted by a particular service provider. Each token grants access to a specific site against a specific source for a specified duration. [12]

OAuth provides access to third-party sites to access their information stored on other service providers without having to share their access or overall data permissions. How it works is similar to using a credit card and signing a transaction slip, without giving out its ATM card and PIN.

\section{ApiKeyThe}

ApiKey is one of the authentication methods to access API from another website. Usually in the form of code taped to other applications. Some Open APIs use ApiKey for access, and few others do not use it. To obtain an ApiKey, a user must register to API provider.

\section{OO. Scope}

The scope of our work is the scope API, based on the location where the APIs are implemented at the national or regional level.

PP. Source

Data provided by an open API can be obtained from either origin sources or scraping websites, which can be explained as follows:

\section{Origin Sources}

Origin sources are persons or organizations who created data. The knowledge of the source is for data integrity and validity.

2. Scraping

Scraping is a technology solution to extract data from web sites, in a quick, efficient and automated manner, offering data in a more structured and easier way to use the format [18]. Some software companies have designed different tools that enable other people to use scraping techniques. These tools provide an attractive and powerful user interface like web data extractors, data harvester, crawling tools, or web content mining tools.

QQ. Approval Request

When a user wishes to access an API, sometimes an approval request process pops up, requiring users to complete it before accessing the API. API may be called by the application that creates approval requests in order to submit a newly-created request for the user to the appropriate approver [19] which is automatically approved, or application should approve user manually. 


\section{RESULTS AND DISCUSSION}

We have described the 38 open APIs in Indonesia. We summarized the APIs based on above criteria into two tables. Table 1 consists of the explanation about technology and authentication. Table 2 describes scope, source and approval request.

Most of open APIs in Indonesia employ Restful and JSON, and few APIs support XML. In terms of authentication, API key is widely used in the APIs since it is simpler of usage than that of OAuth. Some APIs that do scrapping on other websites do not require any authentication methods.

As shown in Table 2, it was only Bandung and Aceh that has explicitly provided open API service for accessing city.-related data. $36 \%$ of the APIs display data by scrapping another website. These APIs can be accessed directly without any approval request since the data are publicly available without accessing APIs. In general, the API system can approve the request of API usage; and few APIs still accept request manually using KeyToken.

Table 1. Open API Based on Technology and Authentication

\begin{tabular}{|c|c|c|}
\hline APIs & Technology & Authentication \\
\hline Bukalapak & JSON, REST & $\begin{array}{l}\text { ApiKey, } \\
\text { oAuth }\end{array}$ \\
\hline $\begin{array}{l}\text { Matahari Mall API } \\
\text { for Seller }\end{array}$ & JSON, REST & ApiKey \\
\hline Tiket.com API & $\begin{array}{l}\text { JSON, XML, } \\
\text { PHP } \\
\text { Serialized, } \\
\text { REST }\end{array}$ & ApiKey \\
\hline Bisatopup & JSON, REST & ApiKey \\
\hline Jurnal API & JSON, REST & ApiKey \\
\hline $\begin{array}{l}\text { Midtrans - Payment } \\
\text { gateway }\end{array}$ & JSON, REST & ApiKey \\
\hline iPaymu & $\begin{array}{l}\text { JSON, XML, } \\
\text { REST }\end{array}$ & ApiKey \\
\hline $\begin{array}{l}\text { Hot thread Kaskus } \\
\text { (un-official) }\end{array}$ & JSON, REST & ApiKey \\
\hline Data Jakarta & JSON, REST & ApiKey \\
\hline
\end{tabular}

\begin{tabular}{|c|c|c|}
\hline APIs & Technology & Authentication \\
\hline Kaskus API & JSON, REST & ApiKey \\
\hline $\begin{array}{l}\text { Tanggal Lahiran } \\
\text { Pasaran Zodiak }\end{array}$ & JSON, REST & OAuth \\
\hline Cek Resi & JSON, REST & None \\
\hline Paket ID & JSON, REST & ApiKey \\
\hline Raja Ongkir & JSON, REST & ApiKey \\
\hline Jadwal Shalat & JSON, REST & ApiKey \\
\hline Ayo Donor PMI & JSON, REST & None \\
\hline Halal Product MUI & JSON, REST & None \\
\hline $\begin{array}{l}\text { The departure of } \\
\text { Hajj Estimation }\end{array}$ & JSON, REST & None \\
\hline $\begin{array}{l}\text { Emergency Contact } \\
\text { (Police, Firefighter, } \\
\text { Hospital) }\end{array}$ & JSON, REST & None \\
\hline Kemendag & JSON, REST & None \\
\hline Song Lyrics & JSON, REST & None \\
\hline $\begin{array}{l}\text { Area Name of the } \\
\text { Whole Indonesia }\end{array}$ & JSON, REST & None \\
\hline Lapor! & $\begin{array}{l}\text { XML, JSON, } \\
\text { REST }\end{array}$ & ApiKey \\
\hline Postal Code & JSON, REST & None \\
\hline API Pemilu & $\begin{array}{l}\text { XML, JSON, } \\
\text { REST }\end{array}$ & ApiKey \\
\hline Mandiri e-cash & JSON, REST & ApiKey \\
\hline $\begin{array}{l}\text { API BPJS } \\
\text { Kesehatan }\end{array}$ & JSON, REST & ApiKey \\
\hline API BCA & JSON, REST & OAuth \\
\hline $\begin{array}{l}\text { Open Data Kota } \\
\text { Bandung }\end{array}$ & JSON, REST & ApiKEY \\
\hline API Data KPU & JSON, REST & None \\
\hline Online Pajak & JSON, REST & ApiKey \\
\hline $\begin{array}{l}\text { Open Data Kota } \\
\text { Banda Aceh }\end{array}$ & JSON, REST & None \\
\hline BRI API & JSON, REST & OAuth \\
\hline ATM Bersama API & JSON, REST & OAuth \\
\hline API-H2H Bisnis & JSON, REST & ApiKey \\
\hline Klik Indonesia API & JSON, REST & ApiKey \\
\hline Panel Pedia API & JSON, REST & ApiKey \\
\hline $\begin{array}{l}\text { Portal Data } \\
\text { Indonesia API }\end{array}$ & JSON, REST & ApiKey \\
\hline
\end{tabular}

Table 2. Open API Based on Scope, Source and Approval Request

\begin{tabular}{|c|c|c|c|}
\hline APIs & Scope & Source & $\begin{array}{c}\text { Approval } \\
\text { Request }\end{array}$ \\
\hline Bukalapak & National & $\begin{array}{l}\text { Origin } \\
\text { Source }\end{array}$ & $\begin{array}{l}\text { Automatical } \\
\text { ly approved } \\
\text { by the } \\
\text { system }\end{array}$ \\
\hline $\begin{array}{l}\text { Matahari } \\
\text { Mall API for } \\
\text { Seller }\end{array}$ & National & $\begin{array}{l}\text { Origin } \\
\text { Source }\end{array}$ & $\begin{array}{l}\text { Automatical } \\
\text { ly approved } \\
\text { by the } \\
\text { system }\end{array}$ \\
\hline
\end{tabular}




\begin{tabular}{|c|c|c|c|}
\hline APIs & Scope & Source & $\begin{array}{c}\text { Approval } \\
\text { Request }\end{array}$ \\
\hline $\begin{array}{l}\text { Tiket.com } \\
\text { API }\end{array}$ & National & $\begin{array}{l}\text { Origin } \\
\text { Source }\end{array}$ & $\begin{array}{l}\text { Automatical } \\
\text { ly approved } \\
\text { by the } \\
\text { system }\end{array}$ \\
\hline Bisatopup & National & $\begin{array}{l}\text { Origin } \\
\text { Source }\end{array}$ & $\begin{array}{l}\text { Automatical } \\
\text { ly approved } \\
\text { by the } \\
\text { system }\end{array}$ \\
\hline Jurnal API & National & $\begin{array}{l}\text { Origin } \\
\text { Source }\end{array}$ & $\begin{array}{l}\text { Automatical } \\
\text { ly approved } \\
\text { by the } \\
\text { system }\end{array}$ \\
\hline $\begin{array}{l}\text { Midtrans - } \\
\text { Payment } \\
\text { gateway }\end{array}$ & National & $\begin{array}{l}\text { Origin } \\
\text { Source }\end{array}$ & $\begin{array}{l}\text { Automatical } \\
\text { ly approved } \\
\text { by the } \\
\text { system }\end{array}$ \\
\hline iPaymu & National & $\begin{array}{l}\text { Origin } \\
\text { Source }\end{array}$ & $\begin{array}{l}\text { Automatical } \\
\text { ly approved } \\
\text { by the } \\
\text { system }\end{array}$ \\
\hline $\begin{array}{l}\text { Hot thread } \\
\text { Kaskus (un- } \\
\text { official) }\end{array}$ & National & $\begin{array}{l}\text { Web } \\
\text { scrappin } \\
\text { g }\end{array}$ & $\begin{array}{l}\text { Manually } \\
\text { using } \\
\text { KeyToken }\end{array}$ \\
\hline Data Jakarta & $\begin{array}{l}\text { Regiona } \\
1\end{array}$ & $\begin{array}{l}\text { Origin } \\
\text { Source }\end{array}$ & $\begin{array}{l}\text { Automatical } \\
\text { ly approved } \\
\text { by the } \\
\text { system }\end{array}$ \\
\hline Kaskus API & National & $\begin{array}{l}\text { Origin } \\
\text { source }\end{array}$ & None \\
\hline $\begin{array}{l}\text { Tanggal } \\
\text { Lahiran } \\
\text { Pasaran } \\
\text { Zodiak }\end{array}$ & National & Scraping & None \\
\hline Cek Resi & National & Scraping & None \\
\hline Paket ID & National & Scraping & None \\
\hline Raja Ongkir & National & Scraping & None \\
\hline Jadwal Shalat & National & Scraping & None \\
\hline $\begin{array}{l}\text { Ayo Donor } \\
\text { PMI }\end{array}$ & National & Scraping & None \\
\hline $\begin{array}{l}\text { Halal Product } \\
\text { MUI }\end{array}$ & National & Scraping & None \\
\hline $\begin{array}{l}\text { The departure } \\
\text { of Hajj } \\
\text { Estimation }\end{array}$ & National & Scraping & None \\
\hline $\begin{array}{l}\text { Emergency } \\
\text { Contact } \\
\text { (Police, } \\
\text { Firefighter, } \\
\text { Hospital) }\end{array}$ & National & Scraping & None \\
\hline Kemendag & National & Scraping & None \\
\hline Song Lyrics & National & Scraping & None \\
\hline $\begin{array}{l}\text { List of local } \\
\text { are in } \\
\text { Indonesia }\end{array}$ & National & Scraping & None \\
\hline Lapor! & National & Origin & Manually \\
\hline
\end{tabular}

\begin{tabular}{|c|c|c|c|}
\hline APIs & Scope & Source & $\begin{array}{c}\text { Approval } \\
\text { Request }\end{array}$ \\
\hline & & Source & $\begin{array}{l}\text { using } \\
\text { KeyToken }\end{array}$ \\
\hline Postal Code & National & Scraping & None \\
\hline API Pemilu & National & $\begin{array}{l}\text { Origin } \\
\text { Source }\end{array}$ & $\begin{array}{l}\text { Automatical } \\
\text { ly approved } \\
\text { by the } \\
\text { system }\end{array}$ \\
\hline $\begin{array}{l}\text { Mandiri e- } \\
\text { cash }\end{array}$ & National & $\begin{array}{l}\text { Origin } \\
\text { Source }\end{array}$ & $\begin{array}{l}\text { Manually } \\
\text { using } \\
\text { KeyToken }\end{array}$ \\
\hline API BPJS & National & Origin & Automatical \\
\hline Kesehatan & & Source & $\begin{array}{l}\text { ly approved } \\
\text { by the } \\
\text { system }\end{array}$ \\
\hline API BCA & National & $\begin{array}{l}\text { Origin } \\
\text { Source }\end{array}$ & $\begin{array}{l}\text { Manually } \\
\text { using } \\
\text { KeyToken }\end{array}$ \\
\hline Open Data & Regiona & Origin & Automatical \\
\hline $\begin{array}{l}\text { Kota } \\
\text { Bandung }\end{array}$ & 1 & Source & $\begin{array}{l}\text { ly approved } \\
\text { by the } \\
\text { system }\end{array}$ \\
\hline $\begin{array}{l}\text { API Data } \\
\text { KPU }\end{array}$ & National & $\begin{array}{l}\text { Origin } \\
\text { Source }\end{array}$ & None \\
\hline Online Pajak & National & $\begin{array}{l}\text { Origin } \\
\text { Source }\end{array}$ & None \\
\hline Open Data & Regiona & Origin & Automatical \\
\hline $\begin{array}{l}\text { Kota Banda } \\
\text { Aceh }\end{array}$ & 1 & Source & $\begin{array}{l}\text { ly approved } \\
\text { by the } \\
\text { system }\end{array}$ \\
\hline BRI API & National & $\begin{array}{l}\text { Origin } \\
\text { Source }\end{array}$ & $\begin{array}{l}\text { Manually } \\
\text { using } \\
\text { KeyToken }\end{array}$ \\
\hline $\begin{array}{l}\text { ATM } \\
\text { Bersama API }\end{array}$ & National & $\begin{array}{l}\text { Origin } \\
\text { Source }\end{array}$ & $\begin{array}{l}\text { Manually } \\
\text { using } \\
\text { KeyToken }\end{array}$ \\
\hline $\begin{array}{l}\text { API-H2H } \\
\text { Bisnis }\end{array}$ & National & $\begin{array}{l}\text { Origin } \\
\text { Source }\end{array}$ & $\begin{array}{l}\text { Manually } \\
\text { using } \\
\text { KeyToken } \\
\text { None }\end{array}$ \\
\hline $\begin{array}{l}\text { Klik } \\
\text { Indonesia } \\
\text { API }\end{array}$ & National & $\begin{array}{l}\text { Origin } \\
\text { Source }\end{array}$ & $\begin{array}{l}\text { Automatical } \\
\text { ly approved } \\
\text { by the } \\
\text { system }\end{array}$ \\
\hline $\begin{array}{l}\text { Panel Pedia } \\
\text { API }\end{array}$ & National & $\begin{array}{l}\text { Origin } \\
\text { Source }\end{array}$ & $\begin{array}{l}\text { Automatical } \\
\text { ly approved } \\
\text { by the } \\
\text { system }\end{array}$ \\
\hline $\begin{array}{l}\text { Portal Data } \\
\text { Indonesia } \\
\text { API }\end{array}$ & National & $\begin{array}{l}\text { Origin } \\
\text { Source }\end{array}$ & $\begin{array}{l}\text { Automatical } \\
\text { ly approved } \\
\text { by the } \\
\text { system }\end{array}$ \\
\hline
\end{tabular}




\section{CONCLUSIONS}

We have investigated 38 open APIs in Indonesia from e-commerce, financial, government, and other domains. RESTful is the popular web service for open APIs. JSON is widely used for data format. Some of the open APIs are unofficial API where the data are obtained from scrapping technique.

\section{REFERENCES}

Group Miniwatts Marketing, "TOP 20 COUNTRIES WITH THE HIGHEST NUMBER OF INTERNET USERS." [Online]. Available: http://www.internetworldstats.com/top20.ht $\mathrm{m}$.

Direktorat Aparatur Negara, Kedeputian Politik Hukum Pertahanan dan Keamanan, and Kementrian PPN/Bappenas, "Draft Rencana Strategis Open Government Indonesia 20172019," 2017.

R. Van Welie, J. Abraham, R. Willemsen, and B. Nagelvoort, "Global B2C E-commerce Report 2015,” 2015.

C. Piao and X. Han, "Study on Open APIs of ecommerce platforms and design of a third party application for Taobao," Proc. - IEEE Int. Conf. E-bus. Eng. ICEBE 2010, pp. 184189, 2010.

R. P. Nugroho, "A comparison of open data policies in different countries," Delft University of Technology, 2013.

Yuhefizar, 10 Jam Menguasai Internet, Teknologi \& Aplikasinya + CD. Elex Media Komputindo

Ir. Hendra Wijaya, BS Oracle9i Database. Elex Media Komputindo.

Ali Zaki \& Smitdev Community, SPP AJAX untuk Pemula. Elex Media Komputindo.

a b David M. Kroenke, Database Processing J1.2/9. Erlangga.
Fielding, Roy T.; Taylor, Richard N. (2002-05), "Principled Design of the Modern Web Architecture" (PDF), ACM Transactions on Internet Technology (TOIT) (New York: Association for Computing Machinery) 2 (2): 115-150, ISSN 1533-5399,

M. Rouse, " open API (public API)" [Online]. Available:

http://searchmicroservices.techtarget.com/de finition/open-API

M. Boyd, "Developing the API Mindset: Aguide to using Private, Partner, \& public APIs", Nordic APIs AB, 2015.

C. Wodehouse, " Public APIs vs. Private APIs: What's the Difference?"[Online]. Available : https://www.upwork.com/hiring/developmen t/public-apis-vs-private-apis-whats-thedifference/

J. David, J. Euzenat, F. Scharffe, C.T. dos Santos, " The Alignment API 4.0", IOS Press (2010), pp 1-8, 2010.

N. K. Gupta, R. K. Isaac, R. K. Singh, " Maintenance and Analysis of Agricultural Data: A Challenge", International Journal of Bioassays, 2016.

O. C. Fernandez, " Web Scraping: Applications and Tools", European Public Sector Information Platform, Topic Report No. 2015/10, 2015.

P. Gune, A. Deighton, M. Chen, R. Kuo, W. Walcott, " User Interface for Processing Requests for Approval" United States Patent Application Publication, 2010.

H. Husein, T. Anggraini, D. Setiawaty, D. Rady, "API Pemilu: Toward the Smart Election".

Kusumawardani, R. P., Rakhmawati, N. A., Wibowo, R. P., Hafidz, I., \& Pranantha, D. (2015). A Prototype of MonVis-Musrenbang: Monitoring and Visualization Application for Surabaya Development Plan. ISICO 2015, 2015. 